1971

\title{
Two Papyrus Fragments of the Odyssey
}

James G. Keenan

Loyola University Chicago, jkeenan@luc.edu

Follow this and additional works at: https://ecommons.luc.edu/classicalstudies_facpubs

Part of the Classical Literature and Philology Commons, and the Other Classics Commons

\section{Recommended Citation}

Keenan, JG. "Two Papyrus Fragments of the Odyssey" in California Studies in Classical Antiquity, Volume 4 (1971). 199-202.

This Article is brought to you for free and open access by the Faculty Publications and Other Works by Department at Loyola eCommons. It has been accepted for inclusion in Classical Studies: Faculty Publications and Other Works by an authorized administrator of Loyola eCommons. For more information, please contact ecommons@luc.edu. \section{(c) $($ () $\ominus$}

This work is licensed under a Creative Commons Attribution-Noncommercial-No Derivative Works 3.0 License. (c) University of California Press, 1971. 


\section{Two Papyrus Fragments of the Odyssey}

The two papyri edited below are housed in the Rare Books Department of the Bancroft Library on the University of California's Berkeley campus. ${ }^{1}$ Of Roman date, they were summarily described on page 303 of The Tebtunis Papyri Vol. $\mathrm{II}^{2}$ and have listings in Roger A. Pack's Greek and Latin Literary Texts from Greco-Roman Egypt. ${ }^{3}$ The collations which follow are based upon P. von der Mühll's edition (Basel 1946). For fragment no. 1, pertinent excerpts from the apparatus criticus of that edition are reproduced.

\section{1.}

P. Teb. 431 descr. $\quad 7.8 \times 12 \mathrm{~cm}$. Late first/early second century Pack $^{2}$ 1099. Upper portion of a column of Odyssey Book XI containing parts of lines $428-440$. The top margin has been preserved to a height of $5.5 \mathrm{~cm}$.

The hand, comparable to that of P. Lond. III, 732,4 may be assigned to the late first or early second century. ${ }^{5}$ It is medium in

1 I would like to thank Mrs. Leslie Clarke and the staff of Rare Books for their kind assistance. I am grateful to Dr. John Shelton for checking my readings and for suggesting a number of improvements, especially on text no. 1 .

2 Ed. Grenfell and Hunt (London-New York 1907).

3 2nd ed. (Ann Arbor 1965) (Pack2).

4 Partially reproduced as pl. XIX in F. G. Kenyon, The Palaeography of Greek Papyri (Oxford 1899) opposite page 97.

5 Cf. the comments of Bruce E. Donovan, "A Homer Fragment in the Library of Congress," BASP V (1968) 37. 
size, most of the letters being $0.3 \mathrm{~cm}$. high. ${ }^{6}$ The scribe consistently finishes his straight strokes with serifs while maintaining spaces between his letters at a fairly constant $0.2 \mathrm{~cm}$. Iota adscript is found twice, once

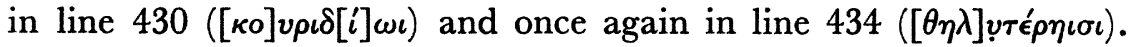
In the second instance the scribe inserted the adscript between the eta and sigma of $[\theta \eta \lambda] v \tau^{\prime} \rho \eta \sigma \iota$ as he was checking over his work. ${ }^{7}$ A grave accent marks the penult of $i \delta \epsilon$ (line 431) to distinguish the conjunction from the verb form $i \delta \epsilon,{ }^{8}$ but the text is otherwise lacking in punctuation or lexical marks.

Written with the fibers on the recto. The verso is blank.

436

440

$$
\text { ].[.].... } \epsilon \tau \alpha \phi \rho \epsilon \sigma \iota \varphi[
$$

$$
] \delta . .[.] \ldots \iota \nu \eta \epsilon \mu \eta \sigma \alpha . o[
$$
]$v \rho \iota[.] \omega \iota \tau \epsilon .[.] \alpha . \alpha \pi \circ \iota \iota[] .[$. ]$\sigma \pi \alpha \sigma \iota \sigma \pi \alpha \iota . . . \sigma[] p. i \delta . .[$ ]$\kappa \alpha \delta \epsilon \lambda \epsilon v \sigma \epsilon \sigma .[..] . \delta \epsilon \xi \circ \chi \alpha .[$

$$
\begin{aligned}
& \text { ]. . } \alpha \tau \alpha \iota \sigma \chi \sigma o \sigma[\ldots] v \epsilon \kappa \alpha \iota \epsilon \sigma .[ \\
& ] . \tau \epsilon \rho \eta \iota \sigma \iota \gamma v \nu[\ldots] \xi \iota \kappa \alpha \iota \eta \kappa[
\end{aligned}
$$
]$\tau \alpha v \tau \alpha \rho \in \gamma[.] \mu \iota \nu \alpha \mu[$

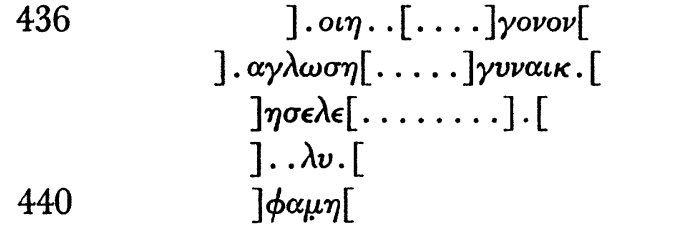

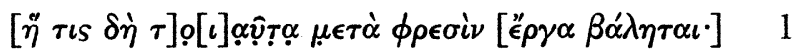

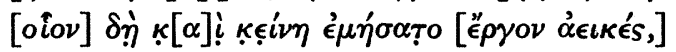

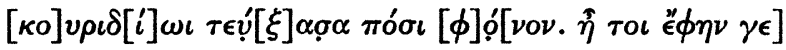

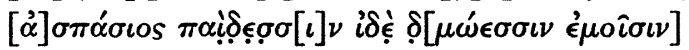

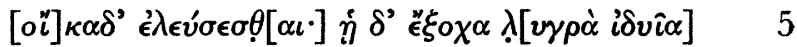

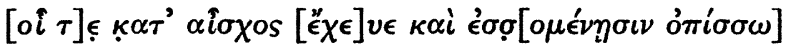

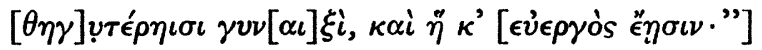

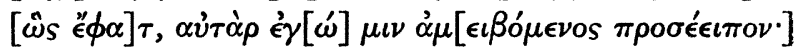

6 The hasta $(0.6 \mathrm{~cm}$. high $)$ of the phi in line 428 makes that letter exceptional.

7 Noted by the editors in their description of P. Teb. 431.

8 For the use of grave accents in similar circumstances see Bernhard Laum, Das alexandrinische Akzentuationssystem unter Zugrundelegung der theoretischen Lehren der Grammatiker und mit Heranziehung der praktischen Verwendung in den Papyri (Paderborn 1928) 400ff. 


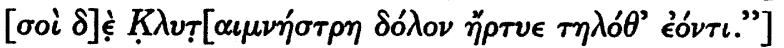

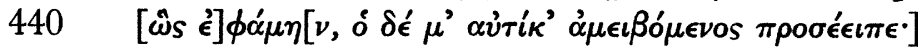

428 "in multis exempl." ant. non tradebatur $434(=\omega 202)$ del.v. Wilamowitz 435-443 damn. Arph. (et Ar.?) $437 \tilde{\epsilon} \chi \theta$. Ar.? (cf. ad P 270. Y 306)

428. $\tau]$ [ $[\iota] \alpha \hat{v} \tau \alpha$ : severe damage to the papyrus renders this reading doubtful as to detail.

430. $\pi \sigma_{\sigma \iota}(\mathrm{read} \pi \dot{\sigma} \sigma \epsilon \iota)$ : confusion between iota and epsilon-iota is extremely frequent in documentary papyri (see E. Mayser, Grammatik der griechischen Papyri aus der Ptolemäerzeit Vol. I, Leipzig, 1906, 87ff), but it is also met with in literary texts (see, e.g., P. Bodmer I intro., p. 26).

2.

P. Teb. 432 descr.

$2.3 \times 5.3 \mathrm{~cm}$.

Second century

Pack $^{2}$ 1156. Extreme upper left-hand corner of a column of Odyssey Book XXIV preserving just the beginnings of lines 501-508. The top and left-hand margins measure respectively 2.0 and $1.0 \mathrm{~cm}$.

In spite of its size and limited content, the fragment contains several points of interest. Among these are the acute accent and diaeresis in line 501 ( $\omega^{\prime} i \xi \alpha[\nu$ : Pap.). The former mark is written very large and extends well beyond the right of the omega it stands over. The epsilon in the left-hand margin, designating line 500 of our papyrus text ( = Vulgate 504), virtually guarantees our papyrus was a professional job, ${ }^{9}$ but it is impossible to tell which four lines of the Vulgate are missing from the papyrus text, or why they are missing. ${ }^{10}$

9 In the sense that line numbering was not primarily intended for the reader's convenience, but to gauge the payment which was owed the scribe for his work. For a full discussion see Kurt Ohly, Stichometrische Untersuchungen, Zentralblatt für Bibliothekswesen, Beiheft 61 (Leipzig 1928), esp. 87ff; cf. E. M. Thompson, Introduction to Greek and Latin Palaeography (Oxford 1912) 68ff; E. G. Turner, Greek Papyri: An Introduction (Princeton 1968) 95. See now Turner, Greek Manuscripts of the Ancient World (Oxford 1971) 19.

10 Many omitted lines in papyrus texts of the Odyssey are paralleled by omissions in the medieval manuscripts; some of the remainder can be traced to scribal errors caused by homoioarchon, homoioteleuton, etc. See the list of P. Collart, "Les papyrus de l'Iliade et de l'Odyssée," RevPhil LXV (1939) 303ff. 
Also in the left-hand margin is a diagonal stroke which the editors in their description of P. Teb. 432 mention as standing "against 1. 507." A reexamination of the papyrus proves it to be standing against line 506 as well: its left-hand terminal is even with the bottom of line 507, but the stroke continues upward and to the right until it almost touches the crossbar of the tau at the start of 506. Its function was to mark the beginning of Odysseus' speech to Telemachos at 506.11

The small, elegant hand was assigned by Grenfell and Hunt to the second century. Most of the letters are $0.2 \mathrm{~cm}$. in height; $\mathrm{xi}$ (line 501) measures $0.25 \mathrm{~cm}$. The sole letter to exceed $0.3 \mathrm{~cm}$. is psi (line 505).

Written with the fibers on the recto of a light tan papyrus. The verso is blank.

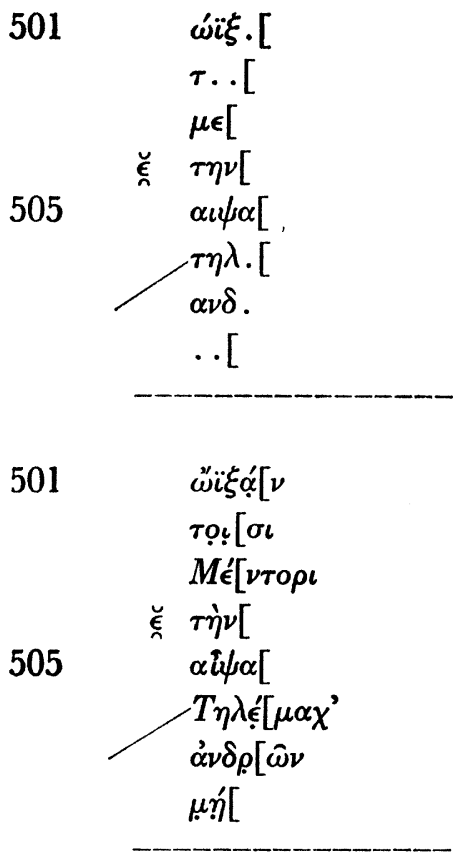

11 The description of $P$. Teb. 432 should be corrected accordingly. So also Ohly's comments on the present text (supra n. 9) 32. For other kinds of "quotation marks" see Thompson (supra n. 9) 63. 


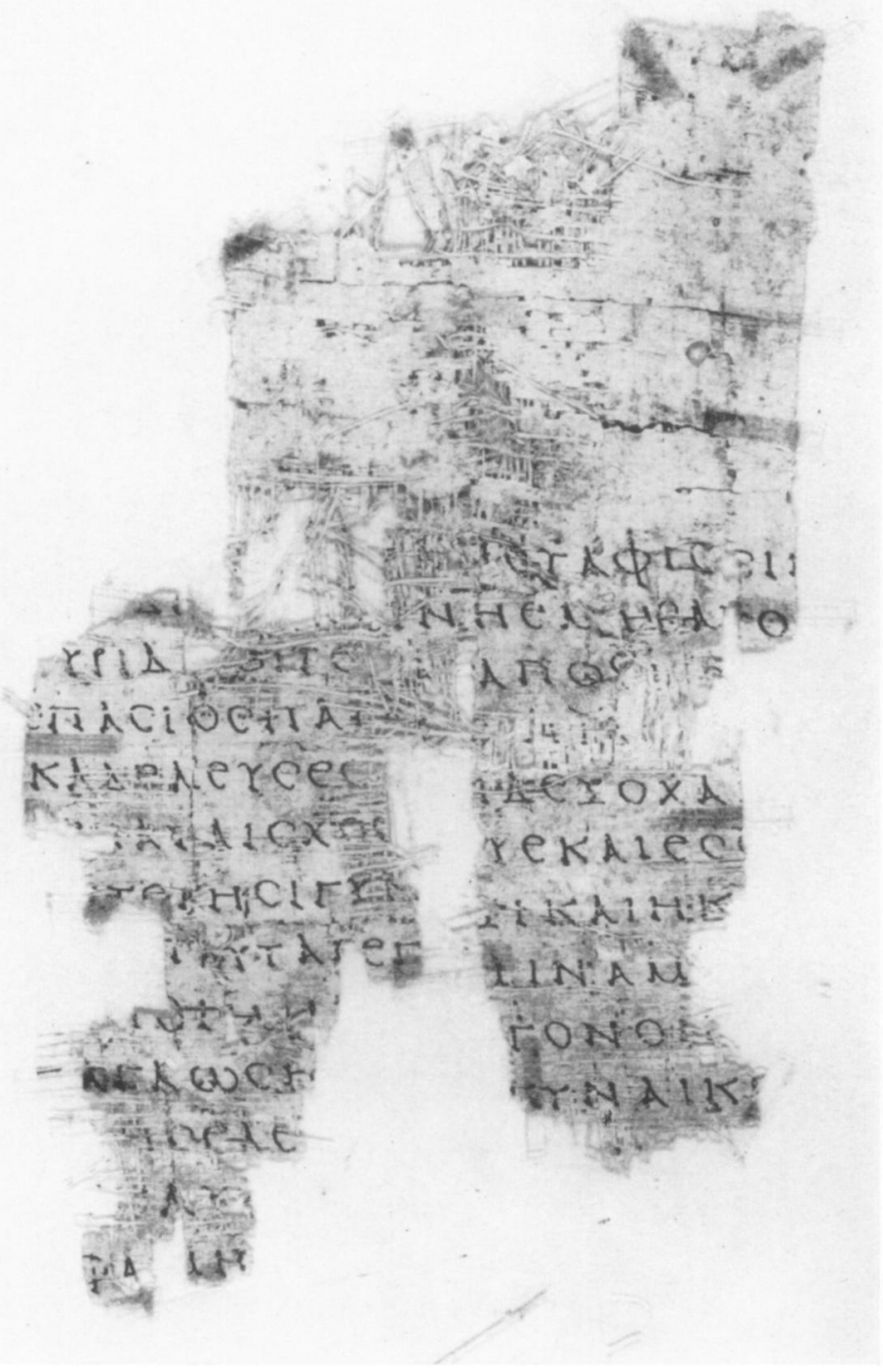

(P. Teb. 431 descr.)—Odyssey XI, 428-440. 


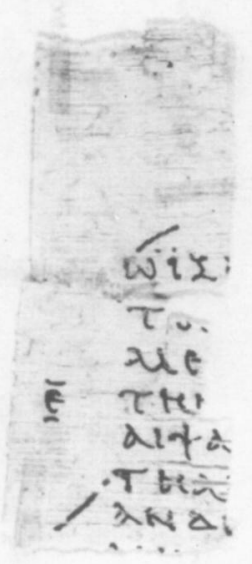

(P. Teb. 432 descr.)

-Odyssey XXIV, 501-508. 